\title{
Model Peningkatan Loyalitas Nasabah Internet Banking Berbasis Persepsi Resiko, Persepsi Privasi dimediasi Kepercayaan dan Kepuasan Nasabah
}

Submitted Date :

20 November 2020

Accepted Date :

8 Februari 2021
Muhammad Ras Muis

Universitas Muhammadiyah Sumatera Utara

muhammadras@umsu.ac.id

Muhammad Fahmi

Universitas Muhammadiyah Sumatera Utara muhammafahmi@umsu.ac.id

Muhammad Andi Prayogi

Universitas Muhammadiyah Sumatera Utara muhammadandi@umsu.ac.id

Jufrizen

Universitas Muhammadiyah Sumatera Utara

jufrizen@umsu.ac.id

\section{Suggested Citation:}

Al-Zu'bi, H. A., \& Ahmad, A. M. K. (2011). E-banking Functionality and Outcomes of Customer Satisfaction:

An Empirical Investigation. International Journal of Marketing Studies, 3(1), 50-65.

\section{Abstract:}

This study aims to examine the factors that influence internet banking customer loyalty in Medan City. The location of this research was carried out at several banks in the city of Medan. The population in this study were all bank customers who use internet banking and the total sample was 175 customers. Researchers used the Structural Equation Modeling assisted by the Lisrel 8.80 program in this research. The results showed that risk perceptions have a negatif and significant effect on customer satisfaction and customer trust. Perception of Privacy has a positive and significant effect on Customer Satisfaction and Customer Trust. Satisfaction has a positive and significant impact on Customer Trust. Perception of risk has a negatif and significant effect on customer loyalty. Perception of Privacy has a positive and insignificant effect on Customer Loyalty. Satisfaction has a positive and significant effect on Customer Loyalty and Trust Has a positive and significant effect on Customer Loyalty. Satisfaction and trust can negatifly mediate the effect of Risk Perception on Customer Loyalty. Satisfaction and trust can positively mediate the effect of Perceptions of Privacy on Customer Loyalty. Trust Satisfaction can positively mediate the effect of satisfaction on Customer Loyalty

Keywords: Loyalty, Perceived Privacy, Perceived Risk, Satisfaction, Trust

\section{Abstrak:}

Penelitian ini bertujuan untuk menguji faktor-faktor yang mempengaruhi loyalitas nasabah internet banking di Kota Medan. Lokasi penelitian ini dilaksanakan pada beberapa Bank di Kota Medan. Populasi dalam penelitian ini adalah semua nasabah bank yang menggunakan internet banking dan jumlah sampel sebanyak 175 orang nasabah. Penelitian menggunakan model Structural Equation Modelling dibantu dengan program Lisrel 8.80. Hasil penelitian menunjukkan bahwa Persepsi Resiko Berpengaruh negatif dan signifikan terhadap Kepuasan Nasabah dan Kepercayaan Nasabah. Persepsi Privasi Berpengaruh positif dan signifikan terhadap Kepuasan Nasabah dan Kepercayaan Nasabah. Kepuasan Berpengaruh positif dan signifikan terhadap Kepercayaan Nasabah. Persepsi Resiko Berpengaruh negatif dan signifikan terhadap Loyalitas Nasabah. Persepsi Privasi Berpengaruh positif dan tidak signifikan terhadap Loyalitas Nasabah. Kepuasan Berpengaruh positif dan signifikan terhadap Loyalitas Nasabah dan Kepercayaan Berpengaruh positif dan signfikan terhadap Loyalitas Nasabah. Kepuasan dan kepercayaan dapat memediasi secara negatif pengaruh Persepsi Resiko terhadap Loyalitas Nasabah. Kepuasan dan kepercayaan dapat memediasi secara positif pengaruh Persepsi Privasi terhadap Loyalitas Nasabah. Kepuasan Kepercayaan dapat memediasi secara positif pengaruh kepuasan terhadap Loyalitas Nasabah.

Kata kunci: Kepercayaan, Kepuasan, Loyalitas, Persepsi Privasi, Persepsi Resiko 
Latar Belakang

Industri perbankan telah menjadi sangat kompetitif dalam pelayanan yang mereka berikan. Teknologi informasi (TI) secara luas banyak digunakan dalam lingkungan yang kompetitif agar bisa memberikan pelayanan perbankan kepada nasabah. Bahkan, munculnya teknologi sistem informasi pada khususnya telah mengubah proses konsumsi perbankan ritel sebagai interaksi masyarakat dalam pemberian pelayanan menjadi semakin berkembang. Oleh karena itu, masyarakat atau interaksi tatap muka antara nasabah dan karyawan bank digantikan oleh interaksi nasabah dengan melalui teknologi. Bahkan sejumlah besar TI yang digunakan untuk meningkatkan efisiensi dan efektivitas pelayanan perbankan. Dengan pola-pola perilaku konsumen yang terus berubah dengan meningkatnya penggunaan teknologi dalam pelayanan perbankan, perlu adanya untuk menumbuhkan kepercayaan nasabah dalam menggunakan pelayanan berbasis teknologi yaitu internet banking (Yaqin \& Ilfitriah, 2014).

Layanan terpopuler di era sekarang adalah Internet Banking atau E-banking yaitu kegiatan melakukan transaksi atau aktivitas perbankan melalui internet dengan platform yang diberikan oleh masing-masing bank. Tujuan utama dari Internet Banking ini untuk mempermudah nasabah melakukan aktivitas perbankan tanpa harus menempuh cara tradisional, seperti mengunjungi kantor bank dan berurusan dengan petugas bank. Layanan Internet Banking akan selalu terkait dengan rekening bank nasabah, sehingga setiap kegiatan perbankan akan terefleksi secara langsung (Rahardjo, 2006).

Dengan adanya layanan Internet Banking, pola interaksi bank dan nasabah menjadi lebih fleksibel. Nasabah dapat mengakses layanan Internet Banking selama terhubung dengan internet untuk melakukan kegiatan perbankan kapanpun dan dimanapun. Adapun jenis kegiatan perbankan yang dapat dilakukan dengan Internet Banking termasuk transfer dana, transfer antar rekening, transfer antar bank domestik, daftar transfer terjadwal, pembayaran, untuk tagihan rekening telepon, internet rumah, kabel TV, kartu kredit, rekening listrik, air, angsuran, asuransi, lain-lain. Internet Banking merupakan suatu aktifitas layanan perbankan yang menggabungkan antara sistem informasi dan teknologi. Fungsi penggunaannya mirip dengan mesin ATM dimana sarananya saja yang berbeda, seorang nasabah dapat melakukan aktifitas pengecekan saldo rekening, transfer dana antar rekening atau antarbank, hingga pembayaran tagihan-tagihan rutin bulanan seperti: listrik, telepon, kartu kredit dan sebagainya.

Berdasarkan fenomena yang terjadi, (Farizi \& Syaefullah, 2014) melakukan penelitian untuk mengetahui persepsi individu apa saja yang berpengaruh terhadap minat penggunaan internet banking. Penelitian mereka mengacu pada penelitian sebelumnya, yaitu penelitian yang dilakukan oleh (Al-Somali, Gholami, \& Clegg, 2009) melakukan penelitian beberapa persepsi yang memengaruhi sikap dan minat diadopsinya internet banking di negara Saudi Arabia. Penelitian ini dilakukan oleh (Pikkarainen, Pikkarainen, Karjaluoto, \& Pahnila, 2004) yang menyelidiki tentang beberapa persepsi dalam penerimaan internet banking di Finlandia.

Loyalitas nasabah adalah komitmen nasabah terhadap suatu produk/jasa berdasarkan sifat yang sangat positif dalam pembelian jangka panjang. Komitmen terhadap produk/jasa diperoleh karena adanya kombinasi dari kepuasan dan keluhan. Sedangkan kepuasan tersebut hadir dari seberapa besar kinerja perusahaan untuk menimbulkan kepuasan tersebut dengan meminimalkan keluhan sehingga diperoleh pembelian jangka panjang yang dilakukan oleh konsumen (Tjiptono, 2012). Loyalitas nasabah merupakan aset penting bagi perusahaan, untuk mempertahankan nasabah yang setia harus mendapatkan prioritas yang lebih besar dibandingkan berusaha untuk mendapatkan pelanggan baru. Nasabah yang setia adalah mereka yang sangat puas dengan produk dan pelayanan tertentu, sehingga mempunyai antusias untuk memperkenalkan kepada siapapun yang mereka kenal. Menurut (Kotler, 2009) loyalitas tinggi adalah pelanggan yang melakukan pembelian dengan presentasi makin meningkat pada perusahaan tertentu dari pada perusahaan lain.

Menurut (Lewis, Agarwal, \& Sambamurthy, 2003), kepercayaan dapat membentuk seseorang dalam hal penggunaan teknologi. Menurut (Dowling \& Staelin, 1994), persepsi risiko adalah suatu persepsi-persepsi nasabah tentang ketidakpastian yang tidak diinginkan dalam melakukan suatu kegiatan penggunaan. Persepsi resiko dan privacy dapat menjadi aspek penting yang dapat mempengaruhi kepuasan dan kepercayaan nasabah dalam bertransaksi secara online (Fatikasari, 2018). (Nazar \& Syahran, 2008) mendefinisikan adalah hak individu untuk mempertimbangkan beberapa dimensi privacy seperti, perilaku, komunikasi, dan data pribadi.

Penelitian tentang loyalitas nasabah internet banking antara lain telah dilakukan oleh (Widyarini, Putro, \& Toni, 2008) dengan hasil penelitian diperoleh bahwa persepsi resiko berpengaruh signifikan terhadap minat menggunakan internet banking; kepercayaan berpengaruh signifikan terhadap minat menggunakan internet banking. Penelitian (Fatikasari, 2018) menunjukkan bahwa persepsi privasi berpengaruh terhadap kepercayaan dan kepuasan. Selanjutnya hasil penelitian (Nawangsari \& Widiastuti, 2018) menunjukan bahwa kepercayaan 
dan mobile banking berpengaruh terhadap kepuasan nasabah. Selanjutnya penelitian (Quan, 2010) menunjukkan bahwa kepuasan nasabah berpengaruh terhadap loyalitas nasabah internet banking.

Menurut (Oliver, 2010), loyalitas adalah komitmen untuk membeli kembali atau menata kembali produk/layanan pilihan secara konsisten di masa depan, sehingga menyebabkan pembelian merek yang sama berulang, meskipun situasional pengaruh dan upaya pemasaran yang berpotensi menyebabkan perilaku beralih. Loyalitas adalah salah satu aspek paling penting bagi pemasar tujuan karena itu lebih diinginkan, dan lebih murah, untuk mempertahankan pelanggan yang sudah ada daripada menarik yang baru (Loureiro \& González, 2008).

Loyalitas pelanggan adalah komitmen pelanggan terhadap suatu merek, toko, atau pemasok, berdasarkan sikap yang positif dan tercermin dalam pembelian ulang yang konsisten (Tjiptono, 2012). Loyalitas pelanggan adalah komitmen pelanggan bertahan secara mendalamuntuk berlangganan kembali atau melakukan pembelian ulang produk/jasa terpilih secara konsisten di masa yang akan datang, meskipun pengaruh situasi dan usaha-usaha pemasaran mempunyai potensi untuk menyebabkan perubahan perilaku (Hurriyati, 2005). Loyalitas konsumen terjadi dalam beberapa fase. Fase tersebut dimulai dari : 1) Loyalitas kognitif (cognitive loyalty) atau loyalitas yang didasarkan hanya pada keyakinan merek. 2) Loyalitas afektif (affective loyalty) atau kesukaan atau sikap terhadap merek didasarkan pada kesempatan menggunakan kepuasan secara kumulatif. 3) Loyalitas konatif (conative loyalty) yang menunjukkan sebuah kondisi loyalitas yang berisi apakah pada kemunculan pertama memperlihatkan komitmen mendalam untuk membeli. 4) Loyalitas tindakan (action loyalty), di mana niat dikonversi ke tindakan (Oliver, 2010). Faktor-faktor yang mempengaruhi loyalitas konsumen adalah sebagai berikut: 1) performa produk/jasa, 2) citra perusahaan/ produk/ merek, 3) hubungan harga dengan nilai, 4) kinerja/prestasi karyawan, 5) persaingan, 6) sistem pengiriman produk tepat waktu, dan 7) hubungan kepuasan dengan konsumen (Cravens \& Piercy, 2013). Pelanggan yang loyal merupakan aset penting bagi perusahaan, hal ini dapat dilihat dari karakteristik yang dimilikinya, sebagaimana diungkapkan oleh (Griffin, 2010) menyebutkan ada empat karakteristik pelanggan yang loyal, yaitu: 1) Melakukan pembelian secara teratur (Makes regular repeat purchases), 2) Membeli di luar lini produk/jasa (Purchases across product and services lines), 3) Merekomendasikan produk lain (Refers other), dan 4) Menunjukkan kekebalan dari daya tarik produk sejenis dari pesaing (Demonstrates an immunity to the full of the competition)

Moorman, Deshpande, \& Zaltman (1993) mengartikan kepercayaan sebagai kemauan seorang individu untuk bergantung pada pihak lain yang terlibat dalam pertukaran. Kim et al., (2008) mendefinisikan kepercayaan sebagai keyakinan subyektif yang akan dilakukan penjual online dalam memenuhi kewajiban transaksionalnya, karena kewajiban tersebut dipahami oleh konsumen. Kepercayaan diukur dalam dua dimensi, yaitu, kompetensi dan kebijakan kompetensi, yang dapat mengarah pada kepercayaan merek (Li, Zhou, Kashyap, \& Yang, 2008). Menurut Pavlou (2003) kepercayaan adalah keyakinan yang membuat konsumen rentan terhadap kebaikan penjual online setelah mempelajari karakteristik mereka. Menurut Pavlou \& Gefen (2004), memahami kepercayaan sebagai kepercayaan umum di penjual online yang menghasilkan niat perilaku. Kepercayaan diakui sebagai faktor yang mempengaruhi kuat niat perilaku offline dan online (Harris \& Goode, 2010). Kepercayaan merupakan keyakinan konsumen akan suatu sikap dan perilaku pihak yang lainnya atau penyedia jasa. Kepercayaan merupakan ekspektasi tiap individu yang akan menjadi konsumen bahwa perusahaan dapat dipercaya dan diandalkan dalam memberikan kepuasan bagi konsumen (Siagian \& Cahyono, 2014). Trust tidak didapat dengan mudah. Kepercayaan harus dibangun mulai dari awal berdirinya suatu usaha hingga implementasi dalam pelaksanaan kegiatan berbisnis. Trust sendiri merupakan sebagai katalis dalam berbagai transaksi antara penjual dan pembeli agar kepuasan konsumen dapat terwujud dan akibatnya akan berdampak kepada minat beli yang semakin tinggi (Yousafzai, Pallister, \& Foxall, 2003).

Kepuasan merupakan reaksi emosional pelanggan pasca-pembelian yang dapat berupa kemarahan, ketidakpuasan, kejengkelan, netralitas, kegembiraan atau kesenangan (Lovelock \& Wright, 2007). Sebagian ahli telah mendefinisikan kepuasan sebagai respons emosional terhadap pembelian yang sukses. Kepuasan sebagai variabel yang signifikan, merupakan faktor kunci untuk menciptakan loyalitas di antara pelanggan (Motameni, Moradi, \& Hemati, 2010). Kepuasan pelanggan adalah persepsi pelanggan bahwa harapannya telah terpenuhi atau terlampaui (Gerson, 2010). Kepuasan pelanggan bermakna perbandingan antara apa yang diharapkan konsumen dengan apa yang dirasakan konsumen ketika menggunakan produk tersebut. Bila konsumen merasakan performa produk sama atau melebihi ekspektasinya, berarti mereka puas. Sebaliknya jika performa 
produk kurang dari ekspektasinya, berarti mereka tidak puas.Kepuasan adalah tingkat perasaan seseorang setelah membandingkan kinerja atau hasil yang dirasakannya dengan harapannya.

Kepuasan adalah pleasureable fulfillment yaitu terpenuhinya harapan pelanggan dengan memuaskan (Oliver, 2010). Kepuasan pelanggan merupakan tingkat perasaan pelanggan setelah membandingkan kinerja layanan yang dirasakan dibanding dengan harapan (Kotler \& Keller, 2016). Kepuasan pelanggan merupakan evaluasi purna beli atau hasil evaluasi setelah membandingkan apa yang dirasakan dengan harapannya (Yamit, 2013). Kepuasan adalah tingkat perasaan setelah membandingkan kinerja atau hasil yang dirasakan dengan harapannya (Sumarwan, 2012). Menilai kepuasan konsumen, menganjurkan penggunaan multi-item scale yaitu tidak saja mengevaluasi kepuasan pelanggan dari sisi layanan perusahaan, tetapi juga komponen dalam proses layanan (Oliver, 2010). Dalam pengukuran kepuasan, indikator yang digunakan adalah: ketanggapan pelayanan, profesionalisme dan kepuasan menyeluruh dengan jasa (Supranto, 2011)

Zheng, Favier, Huang, \& Coat (2012) menyatakan Risiko yang dirasakan adalah ukuran ketidakpuasan yang mungkin atau yang diharapkan dengan keputusan pembelian, berdasarkan tujuan pembelian pembeli. Samadi \& Yaghoob-Nejadi (2009) menyatakan risiko yang dirasakan berarti keyakinan subyektif individu tentang kemungkinan konsekuensi negatif dari keputusannya. Risiko yang dirasakan dianggap konsep dasar perilaku konsumen dan sering digunakan untuk menjelaskan kedua persepsi risiko dan metode pengurangan risiko yang digunakan oleh konsumen (McOmish \& Quester, 2005). Risiko yang dirasakan didefinisikan sebagai sejauh mana seseorang mengekspresikan ketidakpastian tentang suatu layanan atau barang (Dai, Forsythe, \& Kwon, 2014). Kim \& Lennon (2013) mengartikan persepsi risiko sebagai keyakinan konsumen tentang potensi hasil yang tidak pasti dari pembelian online. Schiffman \& Wisenblit (2015) menyatakan perceived risk sebagai ketidakpastian yang dihadapi konsumen ketika mereka tidak dapat melihat konsekuensi dari keputusan pembelian mereka.

Sektor jasa dicirikan oleh tingkat pengalaman dan kepercayaan yang lebih tinggi. Intangibilitas, heterogenitas dan ketidakterpisahan, sebagai karakteristik unik dari layanan, semua berkontribusi pada tingkat pengalaman yang lebih tinggi, di mana tinggi tingkat ketidakpastian bagi konsumen hadir. Risiko yang dirasakan mempengaruhi sikap pembelian online (Lobb, Mazzocchi, \& Traill, 2007), dan memiliki dampak negatif pada sikap pembeli terhadap belanja online (O'Cass \& Fenech, 2003); (Heijden, Verhagen, \& Creemers, 2003) dan tentang perilaku pembelian konsumen (Kovacs, Farias, Moura, \& Souza, 2011). Oleh karena itu, perlu tidak hanya untuk terus memantau dampak negatif dari risiko yang dirasakan pada sikap dan perilaku belanja online konsumen, tetapi juga secara proaktif mengelola dan mengurangi risiko yang dirasakan untuk meningkatkan niat pembelian kembali. Banyak penelitian belum secara sistematis mengeksplorasi bagaimana kepercayaan dan risiko yang dirasakan dapat beroperasi dalam kombinasi untuk mempengaruhi keputusan tersebut (Kim et al., 2008).

Cheung \& Lee, (2006) mendefinisikan privacy adalah kemampuan satu atau sekelompok individu untuk mempertahankan kehidupan dan urusan personalnya dari publik, atau untuk mengontrol arus informasi mengenai diri sendiri. Privasi adalah hak individu untuk mengendalikan penggunaan informasi tentang identitas pribadi baik oleh dirinya sendiri atau oleh pihak lainnya. Secara teknis persepsi keamanan akan menjamin integritas, kerahasiaan, otentifikasi dan tanpa pencatatan transaksi (Flavián \& Guinalíu, 2006). Menurut Flavián \& Guinalíu (2006) integritas suatu sistem informasi mengacu pada kemustahilan dari data yang ditransmisikan atau disimpan akan dapat dimodifikasi oleh pihak ketiga tanpa izin. Kerahasiaan melibatkan data yang hanya dapat dilihat oleh individu yang berwenang. Otentikasi memungkinkan suatu kegiatan tertentu hanya akan dilakukan setelah identifikasi, atau adanya jaminan bahwa identitas hanya digunakan untuk suatu urusan tertentu saja misalnya situs web.

Tanpa pencatatan transaksi (non-repudiation) mengacu pada prosedur yang melindungi individu atau organisasi untuk menyangkal bahwa mereka telah melakukan operasi tertentu misalnya order pembelian. Menurut (Roca, García, \& de la Vega, 2009) keamanan juga melibatkan penggunaan kemajuan teknis yang dapat mempunyai pengaruh yang positif terhadap niat untuk membeli secara online, seperti kriptografi, tanda tangan dan sertifikat digital yang bertujuan untuk melindungi pengguna dari risiko penipuan, hacking atau "phishing". Sementara itu menurut (Armesh, Salarzehi, Yaghoobi, Heydari, \& Nikbin, 2010) masih banyak konsumen yang enggan untuk melepaskan informasi kartu kreditnya kepada penjual online, karena takut kehilangan control atas rekening mereka, sehingga diperlukan evaluasi dalam fitur dan atribut keamanan.

Evaluasi tersebut meliputi kemungkinan: (1) situs tersebut menyediakan enkripsi atau megamankan informasi agar tidak dapat dibaca tanpa bantuan pengetahuan khusus, (2) situs yang mengharuskan pengguna untuk mengatur akun dengan ID dan password, dan (3) konfirmasi di tampilkan layar setelah selesai proses pembelian untuk memastikan akurasi. Selain itu secara khusus (Ahmad \& Ali Al-Zu'bi, 2011) menunjukkan 
pemakaian Secure Socket Layer, yang banyak digunakan di bidang protokoler juga berguna untuk pembayaran kartu kredit secara online. Karena itu, penerapannya perlu dirancang untuk menyediakan: (1) saluran pribadi dan dapat diandalkan dalam komunikasi antara dua entitas, (2) penggunaan Applet Java yang berjalan dalam browser pengguna, (3) penggunaan Personal Identification Number, serta (4) terintegrasinya tanda tangan dan sertifikat digital yang terkait dengan sistem kartu pintar. Menurut (Ahmad \& Ali Al-Zu'bi, 2011) sebuah kombinasi yang menggunakan smart card dan pengakuan biometrik sidik jari menawarkan akses yang lebih aman dan lebih mudah untuk mengontrol komputer daripada metode sandi.

\section{Metode Penelitian}

Penelitian ini menggunakan pendekatan penelitian eksplanatori, yang bertujuan untuk menjelaskan hubungan sebab akibat antara variabel penelitian dan hipotesis pengujian (Nasution dkk., 2020). Lokasi penelitian ini dilaksanakan pada beberapa Bank di Kota Medan baik bank swasta maupun pemerintah. Populasi dalam penelitian ini adalah semua nasabah bank yang menggunakan internet banking dan jumlah sampel sebanyak 175 orang nasabah. Jenis data yang dikumpulkan untuk mendukung variabel yang diteliti adalah bersumber dari data primer dan data sekunder. Teknik pengumpulan data yang digunakan yaitu wawancara (Interview), daftar pertanyaan (Questionaire), dan studi dokumentasi. Dalam penelitian ini peneliti menggunakan model SEM (Structural Equation Modelling) atau pemodelan persamaan struktural dibantu dengan program Lisrel 8.80.

\section{Hasil Penelitian}

\section{Analisis Model Struktural}

Setelah melakukan perhitungan dan analisis terhadap Confirmatory Factor Analysis (CFA), maka dapat diukur latent score variabel (LVS) untuk masing-masing dimensi guna direduksi menjadi indikator pada setiap variabel.

Tabel 1. Goodness of Fit Structural Equation Model (SEM)

\begin{tabular}{ccc} 
Ukuran GoF & Nilai & Tingkat Kecocokan \\
X2/df & 1.37 & GoodFit \\
Root Mean Square Error of & 0.046 & Good Fit \\
Approximation (RMSEA) & 0,99 & Good Fit \\
Non-Normed Fit Index (NNFI) & 0.97 & Good Fit \\
Normed Fit Index (NFI) & 0.96 & Good Fit \\
Relative Fit Index (RFI) & 0,99 & Good Fit \\
Incremental Fit Index (IFI) & 0,99 & Good Fit \\
Comparative Fit Index (CFI) & \\
\hline
\end{tabular}

\section{Sumber: Output LISREL 8.80 Hasil Olahan Peneliti}

Pada Tabel 5.8 di atas kita bisa melihat nilai $X^{2} / \mathrm{df}$ sebesar 1.37 yang masuk ke dalam kategori good fit karena masih dibawah 5. Nilai RMSEA, NFI, dan RFI NNFI, IFI, dan CFI semuanya masuk ke dalam kategori good fit. Jadi dapat disimpulkan bahwa kecocokan keseluruhan model sudah sangat baik.

\section{Analisis Hubungan Kausal}

Setelah menganalisis hasil dari goodness of fit model penelitian, analisis berikutnya yang dilakukan adalah dengan melakukan analisis hubungan kausal pada model. Pengujian statistik untuk hubungan kausal model struktural ini dilakukan dengan tingkat signifikansi $5 \%$ sehingga nilai kritis dari $t$-value adalah \pm 1.96 . Hasil estimasi semua hubungan kausal penelitian bisa dilihat pada hasil outputLISREL 8.80 berikut ini: 
Gambar 1. Model Struktural (t-values)

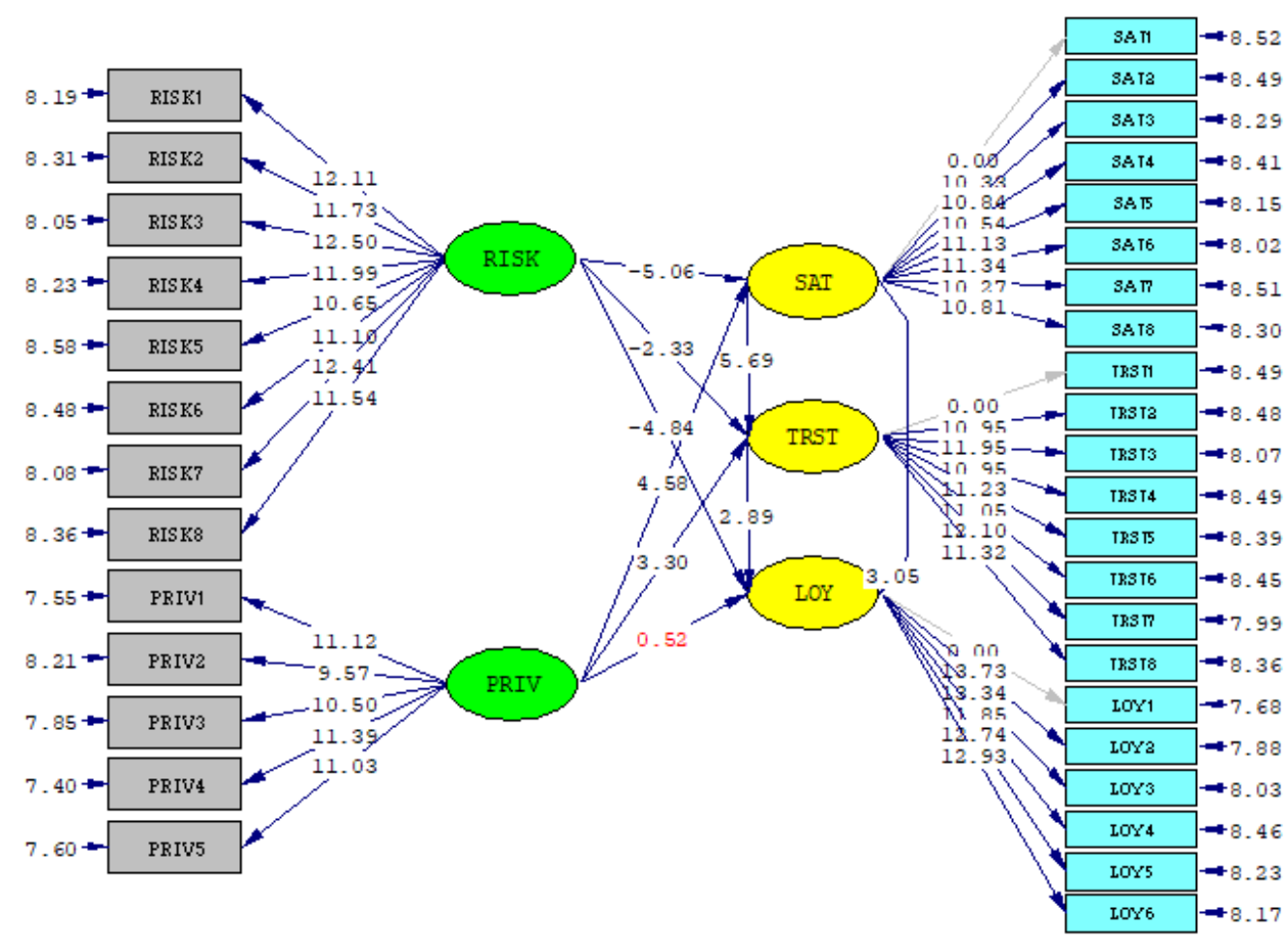

Chi-Square $=754.44, \mathrm{df}=550, \mathrm{P}$-value $=0.00000, \mathrm{RMSEA}=0.046$

Sumber: Output LISREL 8.80 Hasil Olahan Peneliti

Gambar 2. Model Struktural (standardized Solution)

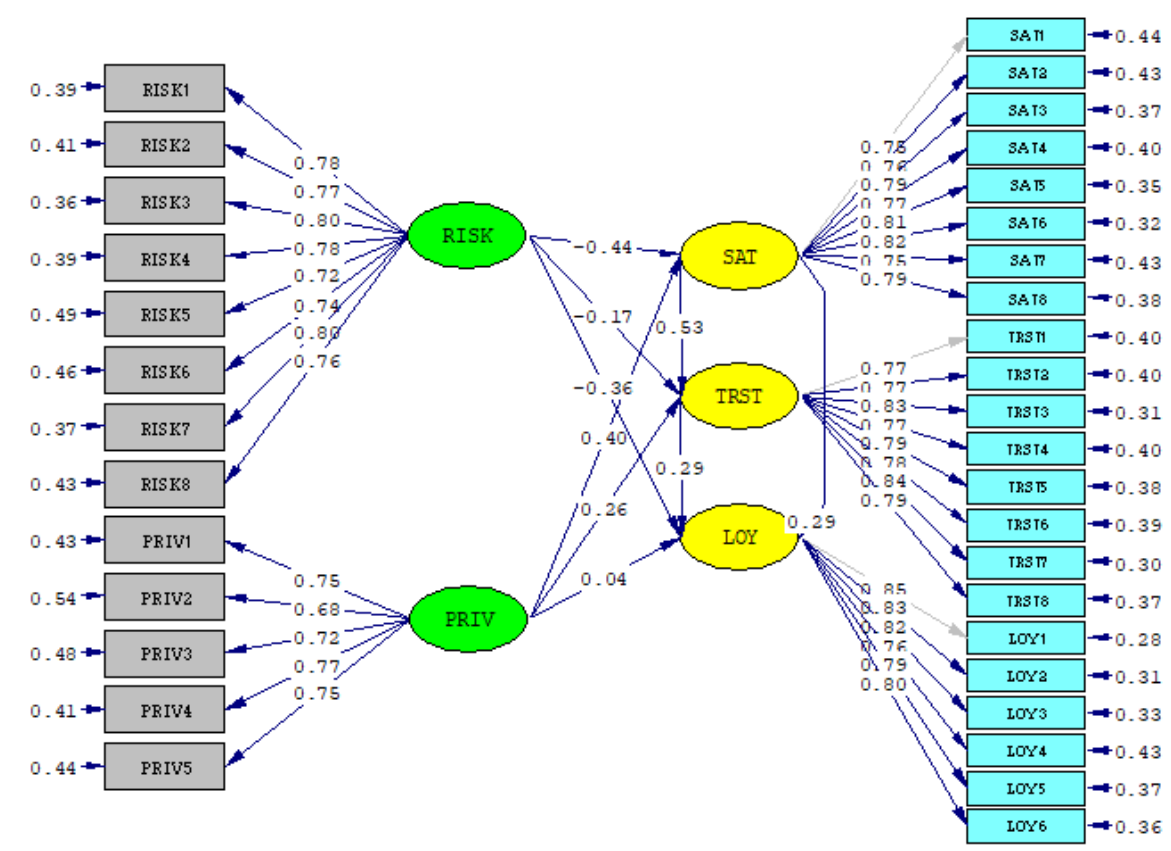

Chi-Square $=754.44, d f=550, P-$ value $=0.00000, \quad$ RMSEA $=0.046$

Sumber: Output LISREL 8.80 Hasil Olahan Peneliti

Dari hasil output LISREL 8.80 untuk persamaan hubungan kausal di atas, dapat dilihat bahwa :

a. T-value dan Koefisien Persamaan Struktural

Dari persamaan kausal di atas, $t$-value yang besar nilai absolutnya> 1.96 memiliki arti bahwa koefisien lintasan tersebut adalah signifikan (Wijanto, 2008). 
Dari gambar di atas, dapat dilihat bahwa terdapat 8 koefisien lintasan yang signifikan dan 1 koefisien lintasan yang tidak signifikan. Interpretasi dari koefisien lintasan yang tersebut akan dijelaskan lebih lanjut pada bagian pengujian hipotesis.

b. Koefisien determinasi $\left(R^{2}\right)$

Structural Equations

$$
\begin{aligned}
& \text { SAT }=-0.44^{*} \text { RISK }+0.40^{*} \text { PRIV, Errorvar. }=0.44, R^{2}=0.56 \\
& \begin{array}{lll}
(0.086) & (0.087) \quad(0.084)
\end{array} \\
& \begin{array}{lll}
-5.06 & 4.58 & 5.28
\end{array} \\
& \text { TRST }=0.53^{\star} \text { SAT }-0.17^{\star} \mathrm{RISK}+0.26^{*} \mathrm{PRIV} \text {, Errorvar. }=0.27, \mathrm{R}^{2}=0.73 \\
& \begin{array}{llll}
(0.092) & (0.074) & (0.078) & (0.053)
\end{array} \\
& \begin{array}{llll}
5.69 & -2.33 & 3.30 & 5.18
\end{array} \\
& \text { LOY }=0.29^{*} \text { SAT }+0.29^{\star} \text { TRST }-0.36^{*} \text { RISK }+0.040^{*} \text { PRIV, Errorvar. }=0.23, R^{2}=0.77 \\
& \begin{array}{lllll}
(0.095) & (0.10) & (0.074) & (0.076) & (0.042) \\
3.05 & 2.89 & -4.84 & 0.52 & 5.46
\end{array}
\end{aligned}
$$

Dari structural form equation di atas dapat dilihat nilai $R^{2}$ masing masing persamaan. Nilai $R^{2}$ berfungsi untuk menunjukkan seberapa besar masing-masing variabel independen mampu menjelaskan variabel dependennya,berikut hasil interpretasi dari koefisien determinasi:

1. Kepuasan memiliki $R^{2}$ sebesar 0.56 , angka ini menunjukkan bahwa Persepsi Resiko dan Persepsi privasi dapat menjelaskan $56 \%$ varian dari Kepuasan, sedangkan sisanya dijelaskan oleh faktor lain.

2. Kepercayaan memiliki $R^{2}$ sebesar 0.73 , angka ini menunjukkan bahwa Kepuasan, Persepsi Resiko dan Persepsi privasi dapat menjelaskan $73 \%$ varian dari Kepercayaan, sedangkan sisanya dijelaskan oleh faktor lain.

3. Loyalitas Nasabah memiliki $\mathrm{R}^{2}$ sebesar 0.77 , angka ini menunjukkan bahwa Kepercayaan, Kepuasan, Persepsi Resiko dan Persepsi privasi dapat menjelaskan $77 \%$ varian dari Loyalitas Nasabah, sedangkan sisanya dijelaskan oleh faktor lain.

\section{Pengujian Hipotesis \\ Pengaruh Langsung}

Seperti sudah dijelaskan pada bab sebelumnya, dalam penelitian ini terdapat 9 (sembilan) hipotesis pada pengaruh langsung. Tabel 3 di bawah ini adalah tabel dari pengujian hipotesis untuk menjawab keseluruhan pertanyaan penelitian.

Tabel 2. Pengujian Hipotesis Model Penelitian H1-H9

\begin{tabular}{clccc}
\hline Hipotesis & \multicolumn{1}{c}{ Pernyataan } & T-Hitung & T-Tabel & Keterangan \\
$\mathrm{H}_{1}$ & $\begin{array}{l}\text { Persepsi Resiko berpengaruh terhadap } \\
\text { Kepuasan }\end{array}$ & -5.06 & & Signifikan \\
$\mathrm{H}_{2}$ & $\begin{array}{l}\text { Persepsi Resiko berpengaruh terhadap } \\
\text { Kepercayaan }\end{array}$ & -2.33 & & Signifikan \\
$\mathrm{H}_{3}$ & $\begin{array}{l}\text { Persepsi privasi berpengaruh terhadap } \\
\text { Kepuasan }\end{array}$ & 4.58 & & Signifikan \\
$\mathrm{H}_{4} \quad \begin{array}{l}\text { Persepsi privasi berpengaruh terhadap } \\
\text { Kepercayaan }\end{array}$ & 3.3 & & Signifikan \\
$\mathrm{H}_{5}$ & $\begin{array}{l}\text { Kepuasan berpengaruh terhadap } \\
\text { Kepercayaan }\end{array}$ & 5.69 & 1,96 & Signifikan \\
$\mathrm{H}_{6}$ & $\begin{array}{l}\text { Persepsi Resiko berpengaruh terhadap } \\
\text { Loyalitas Nasabah }\end{array}$ \\
$\mathrm{H}_{7}$ & $\begin{array}{l}\text { Persepsi Privasi berpengaruh terhadap } \\
\text { Loyalitas Nasabah }\end{array}$ \\
$\mathrm{H}_{8}$ & $\begin{array}{l}\text { Kepuasan berpengaruh terhadap } \\
\text { Loyalitas Nasabah }\end{array}$ & 0.52 & 3.05 & Signifikan \\
$\mathrm{H}_{9}$ & $\begin{array}{l}\text { Kepercayaan berpengaruh terhadap } \\
\text { Loyalitas Nasabah }\end{array}$ & 2.89 & Tidak Signifikan \\
\hline
\end{tabular}

Sumber: Output LISREL 8.80 Hasil Olahan Peneliti 
Berdasarkan tabel di atas yang berisi kesimpulan hasil hipotesis model penelitian, dapat disimpulkan halhal sebagai berikut:

\section{Persepsi Resiko Berpengaruh negatif terhadap Kepuasan Nasabah}

Berdasarkan hasil pengolahan data dari model struktural, diperoleh hasil output berupa $t$-value sebesar 5.06. Hasil $t$-value yang ditunjukkan oleh hipotesis 1 adalah lebih besar dari 1.96, maka dapat disimpulkan bahwa variabel Persepsi Resiko berpengaruh negatif terhadap Kepuasan secara signifikan. Dengan demikian, hipotesis 1 dapat diterima dan dapat disimpulkan bahwa semakin rendah Persepsi Resiko yang dirasakan Responden, maka Kepuasan akan semakin baik pula.

Persepsi Resiko Berpengaruh Negatif terhadap Kepercayaan Nasabah

Berdasarkan hasil pengolahan data dari model struktural, diperoleh hasil output berupa t-value sebesar 2.33. Hasil $t$-value yang ditunjukkan oleh hipotesis 2 adalah lebih besar dari 1.96, maka dapat disimpulkan bahwa variabel Persepsi Resiko berpengaruh negatif terhadap Kepercayaan secara signifikan. Dengan demikian, hipotesis 2 dapat diterima dan dapat disimpulkan bahwa semakin rendah Persepsi Resiko yang dirasakan Responden, maka Kepercayaan akan semakin baik pula.

\section{Persepsi Privasi Berpengaruh positif terhadap Kepuasan Nasabah}

Berdasarkan hasil pengolahan data dari model struktural, diperoleh hasil output berupa $t$-value sebesar 4.58. Hasil $t$-value yang ditunjukkan oleh hipotesis 3 adalah lebih besar dari 1.96, maka dapat disimpulkan bahwa variabel Persepsi Privasi berpengaruh positif terhadap Kepuasan secara signifikan. Dengan demikian, hipotesis 3 dapat diterima dan dapat disimpulkan bahwa semakin baik Persepsi Privasi yang dirasakan Responden, maka Kepuasan akan semakin baik pula.

\section{Persepsi Privasi Berpengaruh positif terhadap Kepercayaan Nasabah}

Berdasarkan hasil pengolahan data dari model struktural, diperoleh hasil output berupa $t$-value sebesar 3.30. Hasil $t$-value yang ditunjukkan oleh hipotesis 3 adalah lebih besar dari 1.96, maka dapat disimpulkan bahwa variabel Persepsi Privasi berpengaruh positif terhadap Kepercayaan secara signifikan. Dengan demikian, hipotesis 4 dapat diterima dan dapat disimpulkan bahwa semakin baik Persepsi Privasi yang dirasakan Responden, maka Kepercayaan akan semakin baik pula.

\section{Kepuasan Berpengaruh positif terhadap Kepercayaan Nasabah}

Berdasarkan hasil pengolahan data dari model struktural, diperoleh hasil output berupa $t$-value sebesar 5.69. Hasil $t$-value yang ditunjukkan oleh hipotesis 5 adalah lebih besar dari 1.96, maka dapat disimpulkan bahwa variabel Kepuasan berpengaruh positif terhadap Kepercayaan secara signifikan. Dengan demikian, hipotesis 5 dapat diterima dan dapat disimpulkan bahwa semakin baik Kepuasan yang dirasakan Responden, maka Kepercayaan akan semakin baik pula.

Persepsi Resiko Berpengaruh negatif terhadap Loyalitas Nasabah

Berdasarkan hasil pengolahan data dari model struktural, diperoleh hasil output berupa $t$-value sebesar 4.84. Hasil $t$-value yang ditunjukkan oleh hipotesis 6 adalah lebih besar dari 1.96, maka dapat disimpulkan bahwa variabel Persepsi Resiko berpengaruh positif terhadap Loyalitas secara signifikan. Dengan demikian, hipotesis 6 dapat diterima dan dapat disimpulkan bahwa semakin rendah Persepsi Resiko yang dirasakan Responden, maka Loyalitas akan semakin baik.

\section{Persepsi Privasi Berpengaruh positif terhadap Loyalitas Nasabah}

Berdasarkan hasil pengolahan data dari model struktural, diperoleh hasil output berupa $t$-value sebesar 0.52 . Hasil $t$-value yang ditunjukkan oleh hipotesis 7 adalah lebih kecil dari 1.96, maka dapat disimpulkan bahwa variabel Persepsi Privasi berpengaruh positif terhadap Loyalitas Nasabah tetapi tidak signifikan. Dengan demikian, hipotesis 4 dapat ditolak dan dapat disimpulkan bahwa semakin baik Persepsi Privasi yang dirasakan Responden, maka tidak berpengaruh terhadap Loyalitas Nasabah.

\section{Kepuasan Berpengaruh positif terhadap Loyalitas Nasabah}

Berdasarkan hasil pengolahan data dari model struktural, diperoleh hasil output berupa t-value sebesar 3.05. Hasil t-value yang ditunjukkan oleh hipotesis 8 adalah lebih besar dari 1.96, maka dapat disimpulkan bahwa variabel Kepuasan berpengaruh positif terhadap Loyalitas Nasabah secara signifikan. Dengan demikian, hipotesis 5 dapat diterima dan dapat disimpulkan bahwa semakin baik Kepuasan yang dirasakan Responden, maka Loyalitas Nasabah akan semakin baik pula. 


\section{Kepercayaan Berpengaruh positif terhadap Loyalitas Nasabah}

Berdasarkan hasil pengolahan data dari model struktural, diperoleh hasil output berupa $t$-value sebesar 2.89. Hasil $t$-value yang ditunjukkan oleh hipotesis 9 adalah lebih besar dari 1.96, maka dapat disimpulkan bahwa variabel Kepercayaan berpengaruh positif terhadap Loyalitas Nasabah secara signifikan. Dengan demikian, hipotesis 9 dapat diterima dan dapat disimpulkan bahwa semakin baik Kepercayaan yang dirasakan Responden, maka Loyalitas Nasabah akan semakin baik pula.

\section{Pengaruh Tidak Langsung}

Dalam penelitian ini terdapat 3 hipotesis untuk pengaruh tidak langsung. Analisis pengujian hipotesis dilakukan dengan tingkat signifikansi $5 \%$, sehingga menghasilkan critical $t$-value sebesar \pm 1.96 . Hipotesis diterima apabila $t$-value yang didapat $\geq 1.96$, sedangkan hipotesis tidak didukung apabila t-value yang didapat < 1.96. berikut ini adalah tabel dari pengujian hipotesis untuk menjawab pengaruh tidak langsung.

Tabel 3. Pengujian Hipotesis Tidak Langsung

\begin{tabular}{lcc}
\multicolumn{1}{c}{ Hipotesis } & \multicolumn{2}{c}{ Intervening } \\
\hline \multicolumn{1}{c}{ Pengaruh Variabel Tidak Langsung (thitung) } & Kepuasan & Kepercayaan \\
$\begin{array}{l}\text { Persepsi Resiko berpengaruh terhadap Loyalitas } \\
\text { Nasabah }\end{array}$ & -4.51 & -4.00 \\
$\begin{array}{l}\text { Persepsi Privasi berpengaruh terhadap Loyalitas } \\
\text { Nasabah }\end{array}$ & 4.32 & 3.88 \\
$\begin{array}{l}\text { Kepuasan berpengaruh terhadap Loyalitas } \\
\text { Nasabah }\end{array}$ & 2.66 & - \\
\hline
\end{tabular}

Sumber: Output LISREL 8.80 Hasil Olahan Peneliti

Berdasarkan tabel di atas yang berisi kesimpulan hasil hipotesis model penelitian, dapat disimpulkan bahwa terdapat 3 (tiga) pengaruh tidak langsung yang signifikan berdasarkan nilai thitung yang lebih besar dari tabel $a=5 \%$ (1.96) yaitu. Pengaruh Persepsi Resiko terhadap Loyalitas Nasabah melalui variabel Kepuasan, dimana merujuk pada tabel dan output nilai $t_{\text {nitung }}$ nya sebesar -4.51 yang lebih besar dari 1.96 , dan bobot pengaruhnya sebesar 0.25 . sedangkan melalui variabel kepercayaan sebesar $-4,00$ yang lebih besar dari 1,96 dan bobot pengaruhnya sebesar 0.23 yang artinya Kepuasan dan kepercayaan dapat memediasi secara negatif pengaruh Persepsi Resiko terhadap Loyalitas Nasabah dengan bobot sebesar -0.25 dan -0.23

Persepsi Privasi berpengaruh terhadap Loyalitas Nasabah melalui variabel Kepuasan, dimana merujuk pada tabel dan output nilai thitung nya sebesar 4.32 yang lebih besar dari 1.96, dan bobot pengaruhnya sebesar 0.25 . sedangkan melalui variabel kepercayaan sebesar 3.88 yang lebih besar dari 1,96 dan bobot pengaruhnya sebesar 0.21 yang artinya Kepuasan dan kepercayaan dapat memediasi secara positif pengaruh Persepsi Privasi terhadap Loyalitas Nasabah dengan bobot sebesar 0.25 dan 0.21

Kepuasan berpengaruh terhadap Loyalitas Nasabah melalui variabel kepercayaan, dimana merujuk pada tabel dan output nilai thitung nya sebesar 2.66 yang lebih besar dari 1.96, dan bobot pengaruhnya sebesar 0.15 yang artinya Kepercayaan dapat memediasi secara positif pengaruh kepuasan terhadap Loyalitas Nasabah dengan bobot sebesar 0.15

\section{Pembahasan}

\section{Pengaruh Persepsi Resiko terhadap Kepuasan Nasabah}

Berdasarkan hasil pengolahan data dari model struktural, diperoleh hasil output berupa $t$-value sebesar 5.06. Hasil $t$-value yang ditunjukkan oleh hipotesis 1 adalah lebih besar dari 1.96, maka dapat disimpulkan bahwa variabel Persepsi Resiko berpengaruh negatif terhadap Kepuasan secara signifikan. Dengan demikian, hipotesis 1 dapat diterima dan dapat disimpulkan bahwa semakin rendah Persepsi Resiko yang dirasakan Responden, maka Kepuasan akan semakin baik pula. Menurut Mulyono, (2012) walaupun tingkat resiko yang dihadapi konsumen tinggi tetapi kepuasan konsumen tetap meningkat. Ltifi \& Gharbi, (2012) menyatakan bahwa risiko kehilangan waktu yang terkait dengan belanja Internet memiliki dampak negatif pada e-kepuasan. Hasil di atas mendukung penelitian (Afwa, Samsir, \& Sulistyowati, 2014), (Bashar \& Wasiq, 2013) dan (Lee \& Joshi, 2007) yang menyatakan bahwa persepsi resiko berhubungan negatif terhadap kepuasan konsumen, dengan kata lain semakin tinggi tingkat resiko maka akan semakin rendah tinggkat kepuasan. 


\section{Pengaruh Persepsi Resiko terhadap Kepercayaan Nasabah}

Berdasarkan hasil pengolahan data dari model struktural, diperoleh hasil output berupa t-value sebesar 2.33. Hasil $t$-value yang ditunjukkan oleh hipotesis 2 adalah lebih besar dari 1.96, maka dapat disimpulkan bahwa variabel Persepsi Resiko berpengaruh negatif terhadap Kepercayaan secara signifikan. Dengan demikian, hipotesis 2 dapat diterima dan dapat disimpulkan bahwa semakin rendah Persepsi Resiko yang dirasakan Responden, maka Kepercayaan akan semakin baik pula. Hal ini sependapat dengan (Ling, Daud, Piew, Keoy, \& Hassan, 2011) dalam penelitiannya juga menjelaskan persepsi teknologi dan persepsi resiko berhubungan terhadap kepercayaan online. Begitu juga (Cheung \& Lee, 2006) menjelaskan Persepsi resiko mempunyai pengaruh paling besar mempengaruhi kepercayaan. Sedangkan menurut (Chang \& Chen, 2008) persepsi resiko berpengaruh signifikan terhadap kepercayaan. Kepercayaan akan meningkat karena turunnya tingkat risiko yang dirasakan, semakin rendah tingkat risiko yang dirasakan maka meningkatkan kepercayaan. Kemudian (Schoorman, Mayer, \& Davis, 2007) dan (Purbasari, 2017) menemukan bahwa persepsi resiko mempengaruhi kepercayaan, persepsi resiko dipercaya dapat mengurangi kepercayaan. Beberapa penelitian lain menyimpulkan bahwa persepsi resiko berpengaruh positif terhadap kepercayaan (Putra, Dantes, \& Candiasa, 2017); (Royani, Kusyanti, \& Aryadita, 2018); (Wanda, Kusumawati, \& Sanawiri, 2018); (Benazić \& Tanković, 2015).

\section{Pengaruh Persepsi Privasi terhadap Kepuasan Nasabah}

Berdasarkan hasil pengolahan data dari model struktural, diperoleh hasil output berupa $t$-value sebesar 4.58. Hasil $t$-value yang ditunjukkan oleh hipotesis 3 adalah lebih besar dari 1.96, maka dapat disimpulkan bahwa variabel Persepsi Privasi berpengaruh positif terhadap Kepuasan secara signifikan. Dengan demikian, hipotesis 3 dapat diterima dan dapat disimpulkan bahwa semakin baik Persepsi Privasi yang dirasakan Responden, maka Kepuasan akan semakin baik pula. Kassim \& Abdullah, (2010), menyatakan bahwa penanganan privasi perlu mengacu pada perlindungan berbagai jenis data yang dikumpulkan (dengan atau tanpa pengetahuan pengguna) selama interaksi antara pengguna dengan sistem online. Chung \& Shin, (2009) menyatakan bahwa perlindungan terhadap privasi adalah penting untuk meningkatkan kepuasan. Hasil penelitian ini sesuai dengan bukti empiris yang diperoleh dari hasil penelitian (Jin \& Park, 2006) serta (Al-Zu'bi \& Ahmad, 2011). Hal ini berarti bahwa semakin baik persepsi keamanan dan privasi konsumen online akibat penawaran penjual atau produsen, maka semakin tinggi pula kepuasan yang akan diterima oleh konsumen tersebut.

\section{Pengaruh Persepsi Privasi terhadap Kepercayaan Nasabah}

Berdasarkan hasil pengolahan data dari model struktural, diperoleh hasil output berupa $t$-value sebesar 3.30. Hasil $t$-value yang ditunjukkan oleh hipotesis 3 adalah lebih besar dari 1.96, maka dapat disimpulkan bahwa variabel Persepsi Privasi berpengaruh positif terhadap Kepercayaan secara signifikan. Dengan demikian, hipotesis 4 dapat diterima dan dapat disimpulkan bahwa semakin baik Persepsi Privasi yang dirasakan Responden, maka Kepercayaan akan semakin baik pula. Richards \& Hartzog, (2016) menyatakan bahwa secara sederhana privasi penting karena memungkinkan kepercayaaan. Hal ini, disebabkan karena saat nasabah bertansaksi menggunakan layanan internet banking, nasabah menilai elemen yang ada dalam privasi nasabah pada layanan internet banking. Kepercayaan terbangun karena adanya harapan bahwa pihak lain akan bertindak sesuai dengan kebutuhan dan keinginan. Selain terhadap kepuasan, persepsi privacy juga dapat berpengaruh secara langsung dan positif terhadap kepercayaan nasabah. Apabila nasabah merasa bahwa informasi pribadi miliknya dilindungi, maka nasabah akan dapat meningkatkan kepercayaan untuk melakukan transaksi. Pernyataan itu didukung oleh penelitian empiris yang telah dilakukan oleh (Flavián \& Guinalíu, 2006) serta (Armesh et al., 2010). Dalam penelitiannya tersebut mereka menghasilkan kesimpulan bahwa persepsi privasi mampu berpengaruh positif terhadap kepercayaan.

\section{Pengaruh Kepuasan Nasabah terhadap Kepercayaan}

Berdasarkan hasil pengolahan data dari model struktural, diperoleh hasil output berupa $t$-value sebesar 5.69. Hasil $t$-value yang ditunjukkan oleh hipotesis 5 adalah lebih besar dari 1.96, maka dapat disimpulkan bahwa variabel Kepuasan berpengaruh positif terhadap Kepercayaan secara signifikan. Dengan demikian, hipotesis 5 dapat diterima dan dapat disimpulkan bahwa semakin baik Kepuasan yang dirasakan Responden, maka Kepercayaan akan semakin baik pula. Kepercayaan terbangun karena adanya harapan bahwa pihak lain akan bertindak sesuai dengan kebutuhan dan keinginan konsumen. Kepuasan merupakan hasil evaluasi atas pengalaman transaksi sebelumnya. Kepuasan akan muncul jika pelanggan menilai positif pengalaman transaksi sebelumnya. Dengan adanya kesan atau penilaian positif dari transaksi sebelumnya maka konsumen akan merasa percaya untuk bertransaksi. Menurut (Kotler \& Amstrong, 2012), kepuasan tergantung pada kinerja 
anggapan produk relatif terhadap ekspektasi pembeli. Jika kinerja produk tidak memenuhi ekspektasi, nasabah kecewa. Jika kinerja produk sesuai dengan ekspektasi, nasabah puas. Jika kinerja melebihi ekspektasi, nasabah sangat puas. Nasabah yang puas tidak hanya menjadikan mereka percaya namun juga mengulangi transaksi, mereka menjadi nasabah pewarta yang memberitahu orang lain tentang pengalaman baik mereka dengan produk bank tersebut. Hasil penelitian (Norhermaya \& Soesanto, 2016) dan (Gultom, Arif, \& Fahmi, 2020), menunjukkan bahwa kepuasan berpengaruh terhadap kepercayaan.

\section{Pengaruh Persepsi Resiko terhadap Loyalitas Nasabah}

Berdasarkan hasil pengolahan data dari model struktural, diperoleh hasil output berupa t-value sebesar 4.84. Hasil $t$-value yang ditunjukkan oleh hipotesis 6 adalah lebih besar dari 1.96, maka dapat disimpulkan bahwa variabel Persepsi Resiko berpengaruh positif terhadap Loyalitas secara signifikan. Dengan demikian, hipotesis 6 dapat diterima dan dapat disimpulkan bahwa semakin rendah Persepsi Resiko yang dirasakan Responden, maka Loyalitas akan semakin baik. Malik, Mahmood, \& Rizwan, (2014) menambahkan bahwa dengan persepsi resiko yang rendah akan membeli kembali dan membeli dalam jangka panjang, sehingga switching cost akan semakin besar. Sebagai hasilnya, loyalitas pelanggan (customer loyalty) juga akan meningkat. Melalui cari ini, pelanggan jarang membeli produk atau jasa yang berisiko tinggi. Beberapa jenis pelanggan ini adalah sebagai pelanggan yang selalu tidak ingin menjalin atau membentuk hubungan dan termasuk pelanggan dengan switching cost yang tinggi. Malik, Mahmood, \& Rizwan, (2014) menyatakan bahwa nasabah mungkin menempatkan persepsi yang berbeda mengenai risiko membeli produk atau jasa dengan risiko. Hasil penelitian (Hafni, Hasibuan, Muslih, \& Yusnandar, 2020) menunjukkan bahwa persepsi resiko berpengaruh terhadap loyalitas nasabah.

\section{Pengaruh Persepsi Privasi terhadap Loyalitas Nasabah}

Berdasarkan hasil pengolahan data dari model struktural, diperoleh hasil output berupa $t$-value sebesar 0.52. Hasil $t$-value yang ditunjukkan oleh hipotesis 7 adalah lebih kecil dari 1.96, maka dapat disimpulkan bahwa variabel Persepsi Privasi berpengaruh positif terhadap Loyalitas Nasabah tetapi tidak signifikan. Dengan demikian, hipotesis 4 dapat ditolak dan dapat disimpulkan bahwa semakin baik Persepsi Privasi yang dirasakan Responden, maka tidak berpengaruh terhadap Loyalitas Nasabah. Kassim \& Abdullah, (2010), menyatakan bahwa penanganan privasi perlu mengacu pada perlindungan berbagai jenis data yang dikumpulkan (dengan atau tanpa pengetahuan pengguna) selama interaksi antara pengguna dengan sistem online. Nasabah yang merasa privasinya dijaga dengan baik dan dilindungi secara hukum oleh pihak bank ketika menggunakan layanan internet banking akan menciptakan loyalitas nasabah. Hasil penelitian ini sesuai dengan bukti empiris yang diperoleh dari hasil penelitian (Jin \& Park, 2006) serta (Al-Zu'bi \& Ahmad, 2011). Hal ini berarti bahwa semakin baik persepsi privasi konsumen online akibat penawaran penjual atau produsen, maka semakin tinggi pula kepuasan yang akan diterima oleh konsumen tersebut dan akan berdampak terhadap loyalitas.

\section{Pengaruh Kepuasan terhadap Loyalitas Nasabah}

Berdasarkan hasil pengolahan data dari model struktural, diperoleh hasil output berupa t-value sebesar 3.05. Hasil $t$-value yang ditunjukkan oleh hipotesis 8 adalah lebih besar dari 1.96, maka dapat disimpulkan bahwa variabel Kepuasan berpengaruh positif terhadap Loyalitas Nasabah secara signifikan. Dengan demikian, hipotesis 5 dapat diterima dan dapat disimpulkan bahwa semakin baik Kepuasan yang dirasakan Responden, maka Loyalitas Nasabah akan semakin baik pula.

Secara teoritis, (Lam, Shankar, Erramilli, \& Murthy, 2004) yang menyatakan bahwa nilai pelanggan mempengaruhi kepuasan dan loyalitas mereka, baik dalam bentuk memberikan rekomendasi maupun melakukan pembelian ulang. Demikian pula dengan penelitian (Cronin, Brady, \& Hult, 2000) yang menyatakan nilai pengorbanan konsumen (SAC) secara tidak langsung mempengaruhi kepuasan konsumen (SAT) dan keinginan membeli kembali behavior intention (BI). Lebih terperinci (Barnes, 2003) menjelaskan bahwa untuk meningkatkan loyalitas, perusahaan harus meningkatkan kepuasan pelanggan dan mempertahankan tingkat kepuasan tersebut dalam jangka panjang. Untuk meningkatkan kepuasan pelanggan, perusahaan harus menambahkan nilai yang dapat membuat mereka mendapatkan apa yang mereka bayar atau lebih dari yang mereka harapkan, sehingga mereka dapat bertahan dan mengarah pada pembelian ulang, perekomendasian, dan proporsi pembelanjaan yang meningkat (Tumbel, 2016). Dalam penelitian ( Radiman, Gunawan, Wahyuni, \& 
Jufrizen, 2018), (Radiman et al., 2018), dan (Azhar, Jufrizen, Prayogi, \& Sari, 2018) menyatakan bahwa kepuasan berpengaruh positif dan signifikan terhadap loyalitas.

\section{Pengaruh Kepercayaan terhadap Loyalitas Nasabah}

Berdasarkan hasil pengolahan data dari model struktural, diperoleh hasil output berupa $t$-value sebesar 2.89. Hasil $t$-value yang ditunjukkan oleh hipotesis 9 adalah lebih besar dari 1.96, maka dapat disimpulkan bahwa variabel Kepercayaan berpengaruh positif terhadap Loyalitas Nasabah secara signifikan. Dengan demikian, hipotesis 9 dapat diterima dan dapat disimpulkan bahwa semakin baik Kepercayaan yang dirasakan Responden, maka Loyalitas Nasabah akan semakin baik pula.

Secara teoritis temuan ini sejalan dengan beberapa penelitian sebelumnya bahwa kepercayaan konsumen berpengaruh terhadap kepuasan dan loyalitas konsumen, seperti pada penelitian (Chu, Ma, \& Vásquez-Párraga, 2018) yang menyatakan bahwa kepercayaan pelanggan sebagai anggota club house atas jasa yang diberikan akan berdampak pada kepuasan dan loyalitas. Secara logika jika ada kepercayaan dalam suatu hubungan maka kedua belah pihak akan saling menjaga sehingga akan memberikan apa yang seharusnya diberikan dan menerima atas apa yang seharusnya diterima, jika harapan sama dengan kenyataan maka itu berarti kepuasan. Ditambahkan pula oleh (Anderson \& Srinivasan, 2003) maupun (Morgan \& Hunt, 1994) bahwa kepercayaan sebagai perasaan percaya terhadap reliabilitas dan integritas partner. Artinya, para nasabah bank tentunya akan mempercayai provider jasa seperti perbankan yang memiliki kehandalan atau keakuratan dan integritas dalam memberikan layanan kepada mereka. Secara teoritis pula, pengaruh kepercayaan konsumen terhadap perilaku membeli ulang sebagai salah satu determinan loyalitas melalui kepuasan konsumen telah dibuktikan dalam beberapa penelitian sebelumnya, seperti pada penelitian (Floh \& Treiblmaier, 2015) yang membuktikan bahwa kepuasan merupakan variabel antara yang penting antara kepercayaan terhadap loyalitas. Jadi secara tidak langsung kepercayaan berpengaruh terhadap loyalitas (Morgan \& Hunt, 1994). Berdasarkan beberapa pendapat mengenai kepercayaan, (Djati \& Ferrinadewi, 2004) menyimpulkan bahwa trust memiliki beberapa elemen penting, yaitu kesediaan dari salah satu pihak untuk menjadi menerima ketidakberdayaannya atas hubungannya dengan orang lain, keyakinan bersama bahwa diantara mereka tidak akan saling memanfaatkan kelemahan mitranya, serta adanya harapan bahwa pihak lain dapat memberikan kepuasan atas kebutuhannya (respon seperti yang diharapkan)

\section{Pengaruh Persepsi Resiko dan Persepsi Privasi terhadap Loyalitas Nasabah Melalui Kepuasan}

Berdasarkan pengolahan data diiperoleh nilai thitung nya sebesar -4.51 yang lebih besar dari 1.96, dan bobot pengaruhnya sebesar 0.25 . sedangkan melalui variabel kepercayaan sebesar $-4,00$ yang lebih besar dari 1,96 dan bobot pengaruhnya sebesar 0.23 yang artinya Kepuasan dan kepercayaan dapat memediasi secara negatif pengaruh Persepsi Resiko terhadap Loyalitas Nasabah dengan bobot sebesar -0.25 dan -0.23 .

Berdasarkan pengolahan data diiperoleh nilai thitung nya sebesar 4.32 yang lebih besar dari 1.96, dan bobot pengaruhnya sebesar 0.25 . sedangkan melalui variabel kepercayaan sebesar 3.88 yang lebih besar dari 1,96 dan bobot pengaruhnya sebesar 0.21 yang artinya Kepuasan dan kepercayaan dapat memediasi secara positif pengaruh Persepsi Privasi terhadap Loyalitas Nasabah dengan bobot sebesar 0.25 dan 0.21 .

Persepsi resiko dan persepsi privasi yang rendah akan membeli kembali dan membeli dalam jangka panjang, sehingga loyalitas nasabah juga akan meningkat. Hasil penelitian ini sesuai dengan bukti empiris yang diperoleh dari hasil penelitian (Jin \& Park, 2006) (Al-Zu'bi \& Ahmad, 2011). Hal ini berarti bahwa semakin baik persepsi resiko dan persepsi privasi, maka semakin tinggi pula kepuasan yang akan diterima oleh konsumen tersebut dan akan berdampak terhadap loyalitas. (Malik et al., 2014) menyatakan bahwa nasabah mungkin menempatkan persepsi yang berbeda mengenai risiko membeli produk atau jasa dengan risiko.

\section{Pengaruh Kepuasan terhadap Loyalitas Nasabah Melalui Kepercayaan}

Berdasarkan pengolahan data diiperoleh nilai thitung nya sebesar 2.66 yang lebih besar dari 1.96, dan bobot pengaruhnya sebesar 0.15 yang artinya Kepercayaan dapat memediasi secara positif pengaruh kepuasan terhadap Loyalitas Nasabah dengan bobot sebesar 0.15 . Hal ini menunjukan bahwa kepuasan nasabah yang tinggi akan berdampak pada variabel kepercayaan nasabah dan akhirnya meningkatkan loyalitas nasabah. Secara teoritis, (Lam et al., 2004) yang menyatakan bahwa nilai nasabah mempengaruhi kepuasan dan loyalitas mereka, baik dalam bentuk memberikan rekomendasi maupun melakukan pembelian ulang.

\section{Kesimpulan}

Berdasarkan analisis dan pembahasan maka ditarik kesimpulan bahwa Persepsi Resiko Berpengaruh negatif dan signifikan terhadap Kepuasan dan Kepercayaan Nasabah. Persepsi Privasi Berpengaruh positif dan signifikan terhadap Kepuasan dan Kepercayaan Nasabah. Kepuasan Berpengaruh positif dan signifikan 
terhadap Kepercayaan Nasabah. Persepsi Resiko Berpengaruh negatif dan signifikan terhadap Loyalitas Nasabah. Persepsi Privasi Berpengaruh positif dan tidak signifikan terhadap Loyalitas Nasabah. Kepuasan Berpengaruh positif dan signifikan terhadap Loyalitas Nasabah dan Kepercayaan Berpengaruh positif dan signfikan terhadap Loyalitas Nasabah. Kepuasan dan kepercayaan dapat memediasi secara negatif pengaruh Persepsi Resiko terhadap Loyalitas Nasabah. Kepuasan dan kepercayaan dapat memediasi secara positif pengaruh Persepsi Privasi terhadap Loyalitas Nasabah. Kepuasan dan kepercayaan dapat memediasi secara positif pengaruh kepuasan terhadap Loyalitas Nasabah internet Banking di Kota Medan. Berdasarkan hasil penelitian dan analisis data yang telah dilakukan, maka saran-saran yang dapat diberikan adalah: Pihak bank harus meningkatkan loyalitas para nasabahnya karena mereka tidak memilih internet banking sebagai satusatunya alat untuk bertransaksi perbankan sehari-hari. Manajemen perbankan perlu mempertahankan loyalitas nasabah mereka melalui upaya memaksimalkan kepuasan dan meningkatkan kepercayaan nasabah terhadap perbankan pada umumnya. Pihak bank juga harus terus meningkatkan keamanan dan perawatan fasilitas agar dapat memuaskan nasabah sehingga dapat meningkatkan loyalitas nasabah. Penelitian selanjutnya diharapkan dapat mempertimbangkan faktor gender dan faktor tingkat pendidikan. Faktor gender karena faktor psikologis antara laki-laki dan perempuan berbeda sehingga dapat menentukan tingkat penggunaan Internet Banking dimana perempuan lebih mudah berminat atau tertarik untuk menggunakan suatu produk yang baru. Faktor tingkat pendidikan karena mayoritas orang yang berpendidikan rendah tidak mengetahui cara menggunakan Internet Banking. Disarankan untuk lebih menekankan pada indikator-indikator pada variabelnya, bukan menekankan pada produk-produk Internet Banking, agar dapat tercapai tujuan yang telah ditentukan.

\section{Daftar Pustaka}

Afwa, A., Samsir, S., \& Sulistyowati, L. (2014). Analisis Pengaruh Persepsi Teknologi, Persepsi Resiko Terhadap Kepercayaan dan Dampaknya Terhadap Kepuasan Belanja Online Mahasiswa di Pekanbaru. Jurnal Ekonomi, 22(3), 1-15.

Al-Somali, S. A., Gholami, R., \& Clegg, B. (2009). An investigation into the acceptance of online banking in Saudi Arabia. Technovation, 29(2), 130-141.

Al-Zu'bi, H. A., \& Ahmad, A. M. K. (2011). E-banking Functionality and Outcomes of Customer Satisfaction: An Empirical Investigation. International Journal of Marketing Studies, 3(1), 50-65.

Anderson, R. E., \& Srinivasan, S. S. (2003). E-Satisfaction and E-Loyalty: A Contingency Framework. Psychology and Marketing, 20(2), 123-138.

Armesh, H., Salarzehi, H., Yaghoobi, N. M., Heydari, A., \& Nikbin, D. (2010). The Effects of Security and Privacy Information on Trust \& Trustworthiness and Loyalty in Online Marketing in Malaysia. International Journal of Marketing Studies, 2(2), 223-234.

Azhar, M. E., Jufrizen, J., Prayogi, M. A., \& Sari, M. (2018). The Role of Marketing Mix and Service Quality on Tourist Satisfaction and Loyalty at Samosir. Journal of tourism, 26.

Barnes, J. G. (2003). Secrets Of Customer Relationship Management (Rahasia Manajemen Hubungan Pelanggan). Yogyakarta: Andi.

Bashar, A., \& Wasiq, M. (2013). E-satisfaction and E-loyalty of Consumers Shopping Online. Global Science Technology, 5(1), 6-19.

Benazić, D., \& Tanković, A. Č. (2015). Impact of Perceived Risk and Perceived Cost on Trust in the Online Shopping Websites and Customer Repurchase Intention. 24th CROMAR Congress (pp. 104-122).

Chang, H.-H., \& Chen, S. W. (2008). The impact of online store environment cues on purchase intention: trust and perceived risk as a mediator. Online Information Review, 32(6), 818-841.

Cheung, C. M. K., \& Lee, M. K. O. (2006). Understanding consumer trust in internet shopping: A multidisciplinary approach. Journal of the American Society for Information Science and Technology, 57(4), 479-492.

Chu, Y., Ma, J., \& Vásquez-Párraga, A. Z. (2018). The drivers and antecedents of satisfaction, trust, commitment and loyalty among Chinese customers. International Journal of Business, 23(2), 151-165.

Chung, K., \& Shin, J. (2009). The Relationship between Site Characteristics, Relationship Quality, and Word of Mouth. International Journal of Business and Information, 4(2), 137-160.

Cravens, D. W., \& Piercy, N. . (2013). Strategic Marketing. New York: McGraw-Hill International Edition.

Cronin, J. J., Brady, M. K., \& Hult, G. T. M. (2000). Assessing the effects of quality, value, and customer 
satisfaction on consumer behavioral intentions in service environments. Journal of Retailing, 76(2), 193218.

Dai, B., Forsythe, S., \& Kwon, W.-S. (2014). The Impact of Online Shopping Experience on Risk Perceptions and Online Purchase Intentions: Does Product Category Matter? Journal of Electronic Commerce Research, 5(1), 13-24.

Djati, S. P., \& Ferrinadewi, E. (2004). Pentingnya Karyawan dalam Pembentukan Kepercayaan Konsumen Terhadap Perusahaan Jasa: (Suatu kajian dan Proposisi). Jurnal Manajemen \& Kewirausahaan, 6(2), 114122.

Dowling, G. R., \& Staelin, R. (1994). A Model of Perceived Risk and Intended Risk-Handling Activity. Journal of Consumer Research, 21(1), 119-134.

Farizi, H., \& Syaefullah. (2014). Pengaruh Persepsi Kegunaan, Persepsi Kemudahan, Persepsi Risiko Dan Kepercayaan Terhadap Minat Menggunakan Internet Banking. Jurnal IImiah Mahasiswa FEB Universitas Brawijaya, 2(1), 1-18.

Fatikasari, C. D. (2018). Pengaruh Persepsi Keamanan, Persepsi Privacy, Dan Brand Awareness Terhadap Kepercayaan Konsumen Online Dengan Kepuasan Sebagai Variabel Mediasi. Universitas Negeri Yogyakarta.

Flavián, C., \& Guinalíu, M. (2006). Consumer trust, perceived security and privacy policy: Three basic elements of loyalty to a web site. Industrial Management \& Data Systems, 106(5), 601-620.

Floh, A., \& Treiblmaier, H. (2015). What Keeps the E-Banking Customer Loyal? A Multigroup Analysis of the Moderating Role of Consumer Characteristics on E-Loyalty in the Financial Service Industry. SSRN Electronic Journal, 7(2), 97-110.

Gerson, R. F. (2010). Mengukur Kepuasan Pelanggan: Panduan Menciptakan Pelayanan Bermutu. Jakarta: PPM.

Griffin, J. (2010). Customer Loyalty How To Earn it, How Keep It I. Kentucky: McGraw - Hill.

Gultom, D. K., Arif, M., \& Fahmi, M. (2020). Determinasi Kepuasan Pelanggan Terhadap Loyalitas Pelanggan Melalui Kepercayaan. Maneggio : Jurnal IImiah Magister Manajemen, 4(2), 171-180.

Hafni, R., Hasibuan, J. S., Muslih, M., \& Yusnandar, W. (2020). Model Empiris Online Trust Dan Repeat Purchase Pelanggan Terhadap Situs E-Commerce. Ekuitas: Jurnal Ekonomi dan Keuangan, 4(2), 266283.

Harris, L. C., \& Goode, M. M. H. (2010). Online servicescapes, trust, and purchase intentions. Journal of Services Marketing, 24(3), 230-243.

Heijden, H. van der, Verhagen, T., \& Creemers, M. (2003). Understanding online purchase intentions: Contributions from technology and trust perspectives. European Journal of Information Systems, 12(1), 4148.

Hurriyati, R. (2005). Bauran Pemasaran dan Loyalitas Konsumen. Bandung: Alfabeta.

Jin, B., \& Park, J. Y. (2006). The moderating effect of online purchase experience on the evaluation of online store attributes and the subsequent impact on market response outcomes. Advances in Consumer Research, 33, 203-211.

Kassim, N., \& Abdullah, N. A. (2010). The effect of perceived service quality dimensions on customer satisfaction, trust, and loyalty in e-commerce settings: A cross cultural analysis. Asia Pacific Journal of Marketing and Logistics, 22(3), 351-371.

Khalaf Ahmad, A. M., \& Ali Al-Zu'bi, H. (2011). E-banking Functionality and Outcomes of Customer Satisfaction: An Empirical Investigation. International Journal of Marketing Studies, 3(1), 50-65.

Kim, D. J., Ferrin, D. L., \& Rao, H. R. (2008). A trust-based consumer decision-making model in electronic commerce: The role of trust, perceived risk, and their antecedents. Decision Support Systems, 44(2), 544564.

Kim, J., \& Lennon, S. J. (2013). Effects Of Reputation and Website Quality on Online Consumers' Emotion, Perceived Risk and Purchase Intention. Journal of Research in Interactive Marketing, 7(1), 33-56.

Kotler, P. (2009). Manajemen Pemasaran. Jakarta: Erlangga.

Kotler, P., \& Amstrong, G. (2012). Principles of Marketing. New Jersey: Pearson Prentice Hall.

Kotler, P., \& Keller, K. L. (2016). Marketing Management (15th ed.). New Jersey: Pearson Education.

Kovacs, M., Farias, S. A. de, Moura, F. T., \& Souza, A. G. de. (2011). Relations between consumer effort, risk reduction strategies, and satisfaction with the e-commerce buying process: the development of a conceptual framework. International Journal of Management, 28(1), 316-395.

Lam, S. Y., Shankar, V., Erramilli, M. K., \& Murthy, B. (2004). Customer value, satisfaction, loyalty, and switching 
costs: An illustration from a business-to-business service context. Journal of the Academy of Marketing Science, 32(3), 293-311.

Lee, K., \& Joshi, K. (2007). An Empirical Investigation Of Customer Satisfaction With Technology Mediated Service Encounters In The Context Of Online Shopping. Journal of Information Technology Management, 18(2), 18-37.

Lewis, W., Agarwal, R., \& Sambamurthy, V. (2003). Sources of Influence on Beliefs about Information Technology Use: An Empirical Study of Knowledge Workers. MIS Quarterly, 27(4), 657-678.

Li, F., Zhou, N., Kashyap, R., \& Yang, Z. (2008). Brand trust as a second-order factor An alternative measurement model. International Journal of Market Research, 50(6), 1-23.

Ling, K. C., Daud, D. bin, Piew, T. H., Keoy, K. H., \& Hassan, P. (2011). Perceived Risk, Perceived Technology, Online Trust for the Online Purchase Intention in Malaysia. International Journal of Business and Management, 6(6), 167-182.

Lobb, A. E., Mazzocchi, M., \& Traill, W. B. (2007). Modelling risk perception and trust in food safety information within the theory of planned behaviour. Food Quality and Preference, 18(2), 384-395.

Loureiro, S. M. C., \& González, F. J. M. (2008). The Importance of Quality, Satisfaction, Trust, and Image in Relation to Rural Tourist Loyalty. Journal of Travel \& Tourism Marketing, 25(2), 117-136.

Lovelock, C. H., \& Wright, L. K. (2007). Manajemen Pemasaran Jasa. Jakarta: PT Indeks.

Ltifi, M., \& Gharbi, J. E. (2012). E-satisfaction and e-loyalty of consumers shopping online. Journal of Internet Banking and Commerce, 17(1), 1-20.

Malik, S., Mahmood, S., \& Rizwan, M. (2014). Examining Customer Switching Behavior in Cellular Industry. Journal of Public Administration and Governance, 4(2), 114-128.

McOmish, M. A., \& Quester, P. (2005). erceived risk and servicescape: The importance of managing the physical evidence in services marketing. SERVSIG Research Conference 2005 (p. 55).

Moorman, C., Deshpande, R., \& Zaltman, G. (1993). Factors Affecting Trust in Market Research Relationships. Journal of Marketing, 57(1), 81-101.

Morgan, R. M., \& Hunt, S. D. (1994). The commitment-trust theory of relationship marketing. Journal of Marketing, 58(3), 20-38.

Motameni, A. ., Moradi, H., \& Hemati, A. (2010). Effect of brand personality on customer loyalty. Business Administration Perspective, 37, 99-106.

Mulyono, R. (2012). Pengaruh Perceived Risk, Kepuasan Konsumen Terhadap Intention to Revisit dan Purchase Intent Pada Konsumen Kaskus Website di Surabaya. Kajian IImiah Mahasiswa Manajemen, 1(1), 6-11.

Nasution, M. I., Fahmi, M., Jufrizen, J., Muslih, M., \& Prayogi, M. A. (2020). The Quality of Small and Medium Enterprises Performance Using the Structural Equation Model-Part Least Square (SEM-PLS). Journal of Physics: Conference Series, 1477(2020), 1-7.

Nawangsari, S., \& Widiastuti, R. (2018). Analisis Pengaruh Kualitas Layanan, Kepercayaan dan Layanan Mobile Banking Terhadap Kepuasan Nasabah Bank (Studi Kasus Pada PT Bank DKI - Depok). SEBATIK, 22(2), $51-55$.

Nazar, R., \& Syahran. (2008). Pegaruh privasi, Keamanan, Kepercayaan dan Pengalaman terhadap Niat untuk bertransaksi secara online. Simposium Nasional Akuntansi XI.

Norhermaya, Y. A., \& Soesanto, H. (2016). Analisis Pengaruh Kepuasan Pelanggan Terhadap Kepercayaan dan Loyalitas Pelanggan Untuk Meningkatkan Minat Beli Ulang (Studi pada Online Store Lazada.co.id). Diponegoro Journal of Management, 5(3), 1-13.

O'Cass, A., \& Fenech, T. (2003). Web retailing adoption: Exploring the nature of internet users web retailing behavior. Journal of Retailing and Consumer Services, 10(2), 81-94.

Oliver, R. L. (2010). Satisfaction: A Behavioral Perpective on The Customer. New York: McGraw-Hill.

Pavlou, P. A. (2003). Consumer Acceptance of Electronic Commerce: Integrating Trust and Risk with the Technology Acceptance Mode. International Journal of Electronic Commerce, 7(3), 101-134.

Pavlou, P., \& Gefen, D. (2004). Building Effective Online Marketplaces with Institution-Based Trust. ICIS 2002 Proceedings., 15(1), 37-59.

Pikkarainen, T., Pikkarainen, K., Karjaluoto, H., \& Pahnila, S. (2004). Consumer acceptance of online banking: An extension of the technology acceptance model. Internet Research, 14(3), 224-235. 
Purbasari, W. (2017). Model Kepercayaan Konsumen pada Situs E-Commerce. Teknikom, 1(1), 39-44.

Putra, I. M. E. W., Dantes, G. R., \& Candiasa, I. M. (2017). Model Pengukuran Tingkat Kepercayaan Pelanggan (Online Trust) Terhadap Situs E-Commerce (Studi Kasus Pada Pelanggan E-Commerce di Provinsi Bali). Journal of Natural Science and Engineering, 1(3), 100-109.

Quan, S. (2010). The Relationships Among E-Service Quality, System Quality, Information Quality and Customer Loyalty: An Empirical Study of Internet Banking in China. Global Journal of Management and Business Research, 10(7), 27-34.

Radiman, R, Gunawan, A., Wahyuni, S. F., \& Jufrizen, J. (2018). The Effect of Marketing Mix, Service Quality, Islamic Values and Institutional Image on Students' Satisfaction and Loyalty. Expert Journal of Marketing, 6(2), 95-105.

Radiman, Radiman, Wahyuni, S. F., Jufrizen, J., Muslih, M., Gultom, D. K., \& Farisi, S. (2018). Effect Of Marketing Mix, Service Quality, And University Image On Student Loyalty. Proceedings of the 1st International Conference on Economics, Management, Accounting and Business, ICEMAB 2018.

Rahardjo, B. (2006). Aspek Teknologi dan Keamanan dalam Internet Banking. Jakarta: Erlangga.

Richards, N. M., \& Hartzog, W. (2016). Taking Trust Seriously in Privacy Law. Stanford Technology Law Review, 19(3), 431-472.

Roca, J. C., García, J. J., \& de la Vega, J. J. (2009). The importance of perceived trust, security and privacy in online trading systems. Information Management and Computer Security, 17(2), 96-113.

Royani, F., Kusyanti, A., \& Aryadita, H. (2018). Analisis Keterkaitan Tingkat Kepercayaan Pengguna Dalam Melakukan Transaksi Online (E-Commerce) Pada Instagram. Jurnal Pengembangan Teknologi Informasi dan IImu Komputer, 2(9), 2735-2741.

Samadi, M., \& Yaghoob-Nejadi, A. (2009). A Survey of the Effect of Consumers' Perceived Risk on Purchase Intention in E-Shopping. Business Intelligence Journal, 2(2), 261-275.

Schiffman, L. G., \& Wisenblit, J. L. (2015). Consumer Behavior (11th ed.). Harlow, United Kingdom: Pearson Education Limited.

Schoorman, F. D., Mayer, R. C., \& Davis, J. H. (2007). An Integrative Model of Organizational Trust: Past, Present, and Future. Academy of Management Review, 32(2), 344-354.

Siagian, H., \& Cahyono, E. (2014). Analisis Website Quality, Trust dan Loyalty Pelanggan Online Shop. Jurnal Manajemen Pemasaran, 8(2), 55-61.

Sumarwan, U. (2012). Riset Pemasaran dan Konsumen. Bogor: IPB Press.

Supranto, J. (2011). Pengukuran Tingkat Kepuasan Pelanggan Untuk Menaikkan Pangsa Pasar (4th ed.). Jakarta: PT Rineka Cipta.

Tjiptono, F. (2012). Service Management Mewujdukan Pelayanan Prima. Yogyakarta: PT Andi Offset.

Tumbel, A. (2016). Pengaruh Kepercayaan dan Kepuasan terhadap Loyalitas Nasabah pada PT Bank BTPN Mitra Usaha Rakyat Cabang Amurang Kabupaten Minahasa Selatan. Jurnal LPPM Bidang EkoSosBudKum, 3(1), 64-79.

Wanda, D. Y. C., Kusumawati, A., \& Sanawiri, B. (2018). The Influence of Perceived Risk Toward Trust and Its Impact on Purchase Intention (Study on Go-Ride Consumer in Malang City). Jurnal Administrasi Bisnis, 64(1), 145-152.

Widyarini, L. A., Putro, A. Y. W., \& Toni. (2008). Analisis Hubungan Faktor- Faktor Technology Acceptance, Trust dan Risk Pada Niat Nasabah Bank Untuk Menggunakan Internet Banking. The 2nd National Conference UKWMS.

Yamit, Z. (2013). Manajemen Kualitas Produk \& Jasa. Yogyakarta: Ekonisia.

Yaqin, A., \& Ilfitriah, A. M. (2014). Pengaruh Kualitas Pelayanan Terhadap Kepuasan Dan Loyalitas Nasabah Bank Pengguna E-Banking Di Surabaya. Journal of Business and Banking, 4(2), 245-260.

Yousafzai, S. Y., Pallister, J. G., \& Foxall, G. R. (2003). A proposed model of e-trust for electronic banking. Technovation, 23(11), 847-860.

Zheng, L., Favier, M., Huang, P., \& Coat, F. (2012). Chinese consumer perceived risk and risk relievers in eshopping for clothing. Journal of Electronic Commerce Research, 13(3), 255-274. 